\title{
Severe Head Injury: Clinicians' Awareness of the Literature
}

\author{
Michael J Jacka, Amanda Roze Des Ordons, David Zygun, \\ On behalf of the Canadian Neurocritical Care Society
}

\begin{abstract}
Objectives: 1. To determine the awareness of the literature concerning therapeutic manoeuvres in severe closed head injury (CHI) among Canadian critical care clinicians and neurosurgeons, 2. To identify factors that affect utilization of these manoeuvres, and 3. To compare reported appropriateness and frequency of use with \#1 and \#2. Methods: The study design was a systematic scenario-based survey of all neurosurgeons and critical care physicians treating patients with severe CHI in Canada. Results: Fifty-nine of 99 neurosurgeons and 82 of 148 critical care physicians responded (57\%). The majority of respondents were not able to identify the highest level of published evidence for most manoeuvres, except for the avoidance of corticosteroids (51\%). The factor identified by most respondents as being most important in motivating use of any given manoeuvres was the level of published evidence $(25 \%)$. Although reported appropriateness and frequency of use of most manoeuvres correlated well with each other, they did not correlate with awareness of evidence. In the case of corticosteroids, there was a strong correlation between non-use of steroids and awareness of evidence $(R=-0.30, p=0.0003)$. Conclusions: Respondents to this survey of Canadian physicians treating patients with severe head injury reported published evidence as being the most significant factor affecting use of a therapy. However, most respondents did not correctly identify the highest published level of evidence for most therapies. This study has identified difficulty with research translation that may have clinical implications.
\end{abstract}

RÉSUMÉ: Traumatisme crânien sévère : connaissance de la littérature chez les cliniciens. Objectifs: 1 . Déterminer le niveau de connaissance de la littérature concernant les manœuvres thérapeutiques dans le traumatisme crânien fermé sévère (TCF) chez les cliniciens et les neurochirurgiens canadiens qui dispensent des soins aux grands blessés ; 2. Identifier les facteurs qui influencent ces manœuvres et 3 . Comparer la pertinence et la fréquence de leur utilisation par ces intervenants. Méthodes : Il s'agit d'une enquête systématique basée sur des scénarios, qui s'adresse à tous les neurochirurgiens et les médecins qui travaillent dans une unité de soins intensifs et qui traitent des patients présentant un TCF au Canada. Résultats : Cinquante-neuf des 99 neurochirurgiens et 82 des 148 médecins travaillant dans un service de soins aux grands blessés ont répondu (57\%). La majorité des répondants n'étaient pas capables d'identifier le niveau le plus élevé de preuves publiées pour la plupart des manœuvres sauf en ce qui a trait à l'abstention d'administrer des corticostéroïdes (51\%). Le facteur identifié par la plupart des répondants comme étant le plus important dans la décision d'utiliser telle ou telle manœuvre était le niveau de preuve publié (25\%). Bien que la pertinence et la fréquence d'utilisation de la plupart des manœuvres étaient bien corrélées entre elles, elles n'étaient pas corrélées à la connaissance des preuves. Il existait une forte corrélation entre la non-utilisation des stéroïdes et la connaissance des preuves $(r=-0,30 ; p=0,0003)$. Conclusions : Les répondants à cette enquête chez les médecins canadiens qui traitent des patients atteints de traumatisme crânien sévère ont rapporté que les preuves publiées étaient le facteur le plus important pour déterminer l'utilisation d'un traitement. Cependant, la plupart des répondants n'ont pas identifié correctement le niveau de preuve le plus élevé publié pour la plupart des traitements. Cette étude a identifié la difficulté de transposer la recherche en pratique, ce qui peut avoir des implications cliniques.

Can. J. Neurol. Sci. 2008; 35: 458-471.

Severe closed head injury $(\mathrm{CHI})$ remains a significant clinical and public health problem, with the Canadian incidence estimated at 11.4 per $100000 .^{1}$ The frequency of use and inferred appropriateness among Canadian critical care physicians and neurosurgeons of preventive and therapeutic interventions for severe CHI were described recently. ${ }^{2}$ However, the perceived levels of evidence as well as practice-related factors on which clinicians determine the frequency and appropriateness of use of these interventions remain unknown.

The purposes of this investigation were to determine: 1. the awareness of the literature concerning therapeutic manoeuvres in severe closed head injury among Canadian critical care clinicians and neurosurgeons, 
2. factors that affect utilization of these manoeuvres,

3 . the relationship between reported appropriateness and frequency of use with \#1 and \#2.

\section{METHODS}

The sampling frame was a census of neurosurgeons and critical care physicians treating patients with severe $\mathrm{CHI}$ in Canada. The study design was a systematic survey of all physicians in the census. Study approval was obtained from the University of Alberta Health Research and Ethics Board. Since this was a self-completed survey, consent was implied by survey response. The voluntary nature and study purpose were described in the survey cover letter. The text of the survey has been previously published. ${ }^{2}$

The Canadian Hospitals Directory was reviewed to identify all Canadian hospitals. The administrative physicians of each hospital were contacted by telephone to verify whether patients with severe $\mathrm{CHI}$ were admitted and treated, or generally transferred. In all hospitals where patients with severe CHI were admitted and treated, the heads of the intensive care unit (ICU) and department of neurosurgery (NS) were contacted by telephone or electronic mail (email) to identify all critical care physicians and neurosurgeons directly involved in treating patients with severe CHI. These physicians became the sampling frame of the study.

\section{Table 1: Descriptors of response group}

\begin{tabular}{|c|c|c|c|}
\hline \multicolumn{2}{|c|}{ Unit Model } & \multicolumn{2}{|c|}{ Practice Type } \\
\hline Open & $3(2.2 \%)$ & Neurosurgery & $59(38.6 \%)$ \\
\hline Open, consultative & $32(23.2 \%)$ & ICU Physician & $94(61.4 \%)$ \\
\hline Closed, consultative & $24(17.4 \%)$ & \multicolumn{2}{|c|}{ ICU Patient Groups } \\
\hline Closed & $79(57.3 \%)$ & Surgical & $1(0.7 \%)$ \\
\hline \multicolumn{2}{|c|}{ Age Groups } & Neurosciences & $16(11.4 \%)$ \\
\hline$<40$ & $62(43.9 \%)$ & Trauma & $2(1.4 \%)$ \\
\hline $40-49$ & $40(28.3 \%)$ & Mixed & $122(86.5 \%)$ \\
\hline $50-59$ & $27(19.2 \%)$ & \multicolumn{2}{|c|}{ Patient Ages } \\
\hline$>60$ & $12(8.5 \%)$ & Adults Only & $106(75.2 \%)$ \\
\hline \multicolumn{2}{|c|}{ Gender } & Adults and Children & $35(24.8 \%)$ \\
\hline Male & $128(90.8 \%)$ & \multicolumn{2}{|c|}{ Residents } \\
\hline Female & $13(92 . \%)$ & Yes & $111(78.7 \%)$ \\
\hline \multicolumn{2}{|c|}{ Certification } & No & $30(21.3 \%)$ \\
\hline $\begin{array}{l}\text { General License } \\
\text { Only }\end{array}$ & 1 & \multicolumn{2}{|c|}{ Referral Pattern } \\
\hline Family Practice & 0 & Secondary & $8(5.7 \%)$ \\
\hline Specialty & 134 & Tertiary & $132(94.3 \%)$ \\
\hline Other & 6 & \multicolumn{2}{|c|}{ Patients Ventilated } \\
\hline \multicolumn{2}{|c|}{ Hospital Size } & $<25 \%$ & $2(1.4 \%)$ \\
\hline $100-400$ beds & $40(24.2 \%)$ & $26-50 \%$ & $20(14.4 \%)$ \\
\hline $400-750$ & $76(55.5 \%)$ & $51-75 \%$ & $47(33.8 \%)$ \\
\hline$>750$ & $21(15.3 \%)$ & $>76 \%$ & $70(50.4 \%)$ \\
\hline \multicolumn{2}{|c|}{ City Population } & \multicolumn{2}{|c|}{ Estimated Incidence } \\
\hline$<50000$ & $1(0.7 \%)$ & Increased & $24(17.5 \%)$ \\
\hline $50000-100000$ & $12(8.6 \%)$ & Decreased & $51(37.2 \%)$ \\
\hline $100000-250000$ & $36(25.7 \%)$ & Same & $62(45.2 \%)$ \\
\hline $250000-500000$ & $21(15.0 \%)$ & \multicolumn{2}{|c|}{ Other Descriptors } \\
\hline$>500000$ & $70(50 \%)$ & Years in Practice & $11.9(9.2)$ \\
\hline \multicolumn{2}{|c|}{ Estimated Survival } & Beds in ICU & $18.9(8.8)$ \\
\hline Increased & $78(56.9 \%)$ & Multitrauma/year & $160.3(165.3)$ \\
\hline Decreased & $1(0.7 \%)$ & $\begin{array}{l}\text { Severe head } \\
\text { injury/year }\end{array}$ & $81.7(78.2)$ \\
\hline Same & $58(42.3 \%)$ & & \\
\hline
\end{tabular}

Table 2: Summary ranking of interventions appropriateness (mean score)

\begin{tabular}{|c|c|c|c|}
\hline Appropriateness & EPI & DAI & IC \\
\hline $\begin{array}{c}\text { Appropriate } \\
(5.0-7.0)\end{array}$ & $\begin{array}{l}\text { Surgery } 6.9 \\
\text { Mannitol 5.6 }\end{array}$ & $\begin{array}{l}\text { Fever Reduction } 6.3 \\
\text { Early Feeding } 6.1 \\
\text { Glucose Control } 6.1 \\
\text { CPP-guided Tx } 6.0 \\
\text { Mannitol 5.6 } \\
\text { Hypertonic Saline } 5.4 \\
\text { Propofol } 5.4 \\
\text { JVO 5.3 } \\
\text { EVD 5.3 } \\
\text { Narcotics } 5.3\end{array}$ & $\begin{array}{l}\text { Early Feeding } 6.3 \\
\text { Glucose Control } 6.3 \\
\text { Fever Reduction } 6.2 \\
\text { CPP-guided Tx } 5.9 \\
\text { Mannitol 5.6 } \\
\text { EVD 5.5 } \\
\text { Hypertonic Saline 5.5 } \\
\text { Narcotics 5.5 } \\
\text { JVO 5.3 } \\
\text { Propofol 5.3 }\end{array}$ \\
\hline $\begin{array}{c}\text { Uncertain } \\
(3.0-4.9)\end{array}$ & $\begin{array}{l}\text { Hypertonic Saline } 4.9 \\
\text { Phenytoin } 4.8 \\
\text { JVO 4.6 } \\
\text { Cooling } 4.6 \\
\text { Hyperventilation } 4.4 \\
\text { EVD 4.4 } \\
\text { Nimodipine } 3.8\end{array}$ & $\begin{array}{l}\text { NMB } 4.7 \\
\text { Hyperventilation } 3.7 \\
\text { Surgery } 3.6\end{array}$ & $\begin{array}{l}\text { Surgery } 4.9 \\
\text { NMB } 4.8 \\
\text { Hyperventilation } 4.0\end{array}$ \\
\hline $\begin{array}{c}\text { Inappropriate } \\
(1.0-2.9)\end{array}$ & Steroids 2.6 & & \\
\hline
\end{tabular}

EPI=epidural hematoma scenario; DAI=diffuse axonal injury scenario; IC $=$ intracranial confusion scenario

Item generation for the survey consisted of a comprehensive Medline search of articles published between 1966 and December 2004. Item reduction was performed by a panel of ten experts in head injury management, including five experts in each of ICU and NS, in order to eliminate bizarre items (e.g. herbal therapy) and those of historical interest only, and to ensure the otherwise comprehensive nature of the items. The survey was based on scenarios that were intended to suggest an acute traumatic epidural hematoma, diffuse small vessel injury and subarachnoid hemorrhage, and intracranial contusion (Appendix). The survey was pilot-tested and retested on the group of experts, and the kappa correlation coefficient was calculated for each response. Responses with a test-retest kappa of 0.75 or less were removed.

The final survey was mailed to each physician of the sampling frame on January 30, 2005. The survey was announced to the departmental head of ICU and NS at each site by fax and email, with suggestions to encourage response. Non-responders to the first mailing were sent a follow-up letter and survey on February 28, 2005. A third mailing was sent to persistent nonresponders on March 30, 2005. Contact with non-responders to the first two mailings was attempted by telephone and email during April 2005.

The medical literature was reviewed using the MEDLINE database from inception until January 2005. The medical subject headings (MESH) considered were 'craniocerebral trauma', 'surgery', 'ventriculostomy', 'jugular veins' and 'oximetry', 'mannitol', 'steroids', 'hypertonic saline', 'cooling', 'nimodipine', 'cerebral' and 'perfusion pressure', 'early' and 'enteral feeding', 'intensive' and 'glucose control', 'fever reduction', 'muscle relaxants', 'propofol', and 'narcotics'. The Boolean operator 'AND' was applied to the search results of 'craniocerebral trauma' and each of the other sets regarding therapeutic manoeuvres. The combined set was then reviewed independently by the authors to determine the highest level of 
Table 3: Summary ranking of interventions frequency (mean score)

\begin{tabular}{|c|c|c|c|}
\hline Frequency & EPI & DAI & IC \\
\hline $\begin{array}{c}\text { Frequent/Always } \\
(3.7-5)\end{array}$ & $\begin{array}{l}\text { Surgery } 4.7 \\
\text { Mannitol } 3.8\end{array}$ & $\begin{array}{l}\text { Fever Reduction } 4.7 \\
\text { Early Feeding } 4.7 \\
\text { Glucose Control } 4.5 \\
\text { CPP-guided Tx } 4.4 \\
\text { Mannitol } 3.9 \\
\text { Narcotics } 3.9\end{array}$ & $\begin{array}{l}\text { Fever Reduction } 4.7 \\
\text { Early Feeding } 4.6 \\
\text { Glucose Control } 4.6 \\
\text { CPP-guided Tx } 4.3 \\
\text { Mannitol } 3.9 \\
\text { Narcotics } 3.9\end{array}$ \\
\hline $\begin{array}{l}\text { Occasional } \\
(2.3-3.7)\end{array}$ & $\begin{array}{l}\text { Phenytoin } 3.2 \\
\text { Hyperventilation } 3.0 \\
\text { EVD } 2.9 \\
\text { Cooling } 2.9\end{array}$ & $\begin{array}{l}\text { Propofol } 3.7 \\
\text { EVD } 3.7 \\
\text { NMB } 2.9 \\
\text { Hyperventilation } 2.8 \\
\text { Hypertonic Saline } 2.7\end{array}$ & $\begin{array}{l}\text { Propofol } 3.7 \\
\text { EVD } 3.6 \\
\text { Surgery } 3.1 \\
\text { NMB } 2.9 \\
\text { Hyperventilation } 2.8 \\
\text { Hypertonic Saline } 2.7\end{array}$ \\
\hline $\begin{array}{c}\text { Rare/Never } \\
(1.0-2.3)\end{array}$ & $\begin{array}{l}\text { Hypertonic Saline } 2.2 \\
\text { JVO } 1.6 \\
\text { Nimodipine } 1.2 \\
\text { Steroids } 1.2\end{array}$ & $\begin{array}{l}\text { Surgery } 2.2 \\
\text { JVO } 1.7\end{array}$ & JVO 1.8 \\
\hline
\end{tabular}

$\mathrm{EPI}=$ epidural hematoma scenario; DAI-diffuse axonal injury scenario; $\mathrm{JC}=$ intracranial confusion scenario

evidence that could be applied to each therapy. Evidence classifications were condensed from the survey into five categories as follows: meta-analysis (including systematic reviews), randomized trials (investigational designs), observational trials (i.e. with comparison groups, e.g. cohort, case-control studies), 'other' literature (case series, expert opinion, physiologic rationale). Disagreements among the authors were resolved by consensus process.

Survey responses were analysed by simple descriptive statistics. Comparisons were made to determine the correlations between reported frequency and appropriateness of use, and level of evidence supporting an intervention. Finally, comparisons between these attributes on the basis of training specialty were made (NS vs ICU). The scores for frequency of use and level of evidence were inverted between the survey and the report in order to facilitate interpretation (e.g. lowest became highest and vice versa).

Survey responses regarding literature hierarchy were grouped as follows: meta-analysis: level 5, randomized trials: level 4, observational trials: level 3, 'other' literature: level 2, and unsure: level 1.

Survey responses were tabulated and analysed using SAS ${ }^{\circledR}$ (Cary, NC). Descriptive and analytic methods were employed, using parametric and non-parametric testing as appropriate. The Bonferroni correction for multiple comparisons was applied as required.

\section{RESULTS}

Thirty-one hospitals in Canada were identified where patients with severe CHI were admitted and treated. At these sites, 247 physicians, including 99 neurosurgeons and 148 critical care physicians, were identified as attending on these patients. Responses were received from 29 of the 31 sites surveyed (both of the non-responding sites were in Quebec). Responses were received from $59 \mathrm{NS}$ and 82 ICU physicians, totaling 141 responses (57\% overall response).
Table 4: Levels of evidence reported by respondents compared with formal literature review (number of respondents)

\begin{tabular}{l|c|c|c|c|c|c}
\hline $\begin{array}{c}\text { 'Evidence } \\
\text { Score' }\end{array}$ & 5 & 4 & 3 & 2 & 1 & \\
\hline $\begin{array}{c}\text { Level of } \\
\text { Evidence }\end{array}$ & $\begin{array}{c}\text { Meta } \\
\text { Analysis }\end{array}$ & $\begin{array}{c}\text { Randomized } \\
\text { controlled } \\
\text { trial }\end{array}$ & $\begin{array}{c}\text { Observational } \\
\text { (Cohort, Case- } \\
\text { Control) }\end{array}$ & Other* & Unsure & $\begin{array}{c}\text { Literature } \\
\text { Review } \\
\text { 'Score' ** }\end{array}$ \\
\hline Surgery & 10 & 6 & 39 & $\mathbf{8 3}$ & 3 & $2^{5}$ \\
\hline EVD & 2 & 9 & $\mathbf{3 6}$ & 60 & 34 & $3^{5,9-10}$ \\
\hline JVO & 2 & $\mathbf{1 5}$ & 33 & 43 & 48 & $4^{28}$ \\
\hline Mannitol & $\mathbf{1 0}$ & 33 & 33 & 51 & 14 & $5^{11}$ \\
\hline Steroids & 29 & $\mathbf{7 0}$ & 14 & 9 & 19 & $4^{8}$ \\
\hline $\begin{array}{l}\text { Hypertonic } \\
\text { saline }\end{array}$ & 2 & $\mathbf{5 5}$ & 31 & 29 & 24 & $4^{12-13}$ \\
\hline $\begin{array}{l}\text { Hyper- } \\
\text { ventilation }\end{array}$ & $\mathbf{1 6}$ & 54 & 31 & 31 & 9 & $5^{17-18}$ \\
\hline Phenytoin & 11 & $\mathbf{4 4}$ & 24 & 25 & 37 & $4^{22,27}$ \\
\hline Cooling & $\mathbf{1 5}$ & 66 & 12 & 27 & 21 & $5^{16,19-20}$ \\
\hline Nimodipine & 9 & $\mathbf{2 4}$ & 21 & 19 & 68 & $4^{24}$ \\
\hline $\begin{array}{l}\text { CPP- } \\
\text { directed } \\
\text { therapy }\end{array}$ & 17 & $\mathbf{4 9}$ & 52 & 21 & 2 & $4^{5,9-10}$ \\
\hline $\begin{array}{l}\text { Early } \\
\text { enteral } \\
\text { feeding }\end{array}$ & $\mathbf{2 0}$ & 53 & 32 & 20 & 16 & $5^{14}$ \\
\hline $\begin{array}{l}\text { Intensive } \\
\text { glucose } \\
\text { control }\end{array}$ & 7 & $\mathbf{6 7}$ & 28 & 21 & 18 & $4^{15}$ \\
\hline $\begin{array}{l}\text { Fever } \\
\text { reduction }\end{array}$ & 6 & $\mathbf{2 3}$ & 51 & 42 & 19 & $4^{25}$ \\
\hline NMB & 5 & $\mathbf{6}$ & 42 & 56 & 32 & $4^{26}$ \\
\hline Propofol & 5 & $\mathbf{1 1}$ & 42 & 52 & 31 & $4^{23}$ \\
\hline \begin{tabular}{l} 
Narcotics \\
\hline
\end{tabular} & 4 & $\mathbf{1 1}$ & 33 & 58 & 42 & $4^{23}$ \\
\hline & & & & & & \\
\hline
\end{tabular}

*Other : Case series, physiologic rationale, personal experience, or expert opinion; ** Numeric references for supporting literature; $\mathrm{EVD}=$ extraventricular drain; JVO=jugular venous oximetry; $\mathrm{CPP}=$ cerebral perfusion pressure; $\mathrm{NMB}=$ neuro-muscular blockade

Considering the demographic characteristics of respondents (Table 1), the majority were male $(90.8 \%)$ and younger than age $40(43.9 \%)$. Respondents had been in practice for an average of 11.9 years. Most ICUs were 'closed' (57.3\%) and included an average of 19 beds, which were occupied by 'adults only' in most cases $(75.2 \%)$. The average hospital was between 400 and 750 beds $(55.5 \%)$ and located in a city of more than $500000(50 \%)$. Respondents estimated the incidence of head injury to be stable or decreasing $(82.4 \%$ ), with a stable or increasing survival $(57.5 \%)$.

The frequency of use and perceived appropriateness of interventions described in this survey have been previously published. ${ }^{2}$ The raw tabulations are reported for reference (Table 2 and 3 ).

For each of the therapeutic manoeuvres, the highest level of evidence reported by clinicians surveyed was compared to the highest level detected by the authors' formal review of the literature; this comparison is presented in Table 4. The proportion of respondents agreeing with the authors' review is described in Table 4 and Table 5.

As shown in Table 4, the mode of the highest level of published evidence cited by survey respondents correlated with the formal literature review in 6 of the 17 manoeuvres considered. However, the mode also constituted a majority of 
Table 5: Appropriateness and frequency of use of therapeutic manoeuvres compared with awareness of published evidence and factors affecting use of manoeuvres

\begin{tabular}{|c|c|c|c|c|c|c|}
\hline & \multirow{2}{*}{$\begin{array}{l}\text { Appropriateness } \\
(1-7, \text { mean })\end{array}$} & \multirow{2}{*}{$\begin{array}{l}\text { Frequency } \\
\qquad(1-5, \\
\text { mean })\end{array}$} & \multicolumn{3}{|c|}{ Awareness of Literature: } & \multirow{2}{*}{$\begin{array}{l}\text { Proportion } \\
\text { Citing } \\
\text { Evidence as } \\
\text { major factor }\end{array}$} \\
\hline & & & $\begin{array}{c}\text { Survey } \\
\text { (1-5 mode) }\end{array}$ & Literature (1-5) & $\begin{array}{c}\text { Agreement } \\
\text { with } \\
\text { Literature } \\
(\%)\end{array}$ & \\
\hline Surgery & 6.9 & 4.7 & 2 & 2 & 59 & 27 \\
\hline EVD & 4.4 & 2.9 & 3 & 3 & 26 & 13 \\
\hline JVO & 4.6 & 1.6 & 3 & 2 & 23 & 15 \\
\hline Mannitol & 5.6 & 3.8 & 4 & 5 & 23 & 23 \\
\hline Steroids & 2.6 & 1.2 & 4 & 4 & 50 & 46 \\
\hline Hypertonic saline & 4.9 & 2.2 & 4 & 4 & 39 & 28 \\
\hline Hyper-ventilation & 4.9 & 3.0 & 4 & 5 & 38 & 31 \\
\hline Phenytoin & 4.8 & 3.2 & 4 & 4 & 31 & 35 \\
\hline Cooling & 4.6 & 2.9 & 4 & 5 & 11 & 38 \\
\hline Nimodipine & 3.8 & 1.2 & 4 & 4 & 17 & 29 \\
\hline CPP-directed therapy & 6.0 & 4.4 & 3 & 4 & 37 & 24 \\
\hline Early enteral feeding & 6.1 & 4.7 & 4 & 5 & 14 & 22 \\
\hline $\begin{array}{l}\text { Intensive glucose } \\
\text { control }\end{array}$ & 6.1 & 4.5 & 4 & 4 & 48 & 22 \\
\hline Fever reduction & 6.3 & 4.7 & 3 & 4 & 36 & 18 \\
\hline NMB & 4.7 & 2.9 & 3 & 4 & 30 & 16 \\
\hline Propofol & 5.4 & 3.7 & 3 & 4 & 9 & 16 \\
\hline Narcotics & 5.3 & 3.9 & 3 & 4 & 2 & 16 \\
\hline
\end{tabular}

$\mathrm{EVD}=$ extraventricular drain; $\mathrm{JVO}=$ jugular venous oximetry; $\mathrm{CPP}=$ cerebral perfusion pressure;

$\mathrm{NMB}=$ neuro-muscular blockade

responses in only 2 of these manoeuvres (surgery: 59\%, and steroids: $50 \%$ ). All of the disagreements (11 of 17 manoeuvres) were due to the existence of higher levels of evidence at the time of the survey than clinicians perceived. The proportion in agreement with the formal literature review ranged from $9 \%$ (narcotics, randomized trial) to 59\% (surgery, other evidence).

\section{Table 6: Factors affecting use of therapeutic manoeuvres*}

\begin{tabular}{l|c|c|c|c|c|c|c}
\hline & Evidence & Availability & $\begin{array}{c}\text { Formal } \\
\text { ICU } \\
\text { policy }\end{array}$ & $\begin{array}{c}\text { Informal } \\
\text { ICU } \\
\text { policy }\end{array}$ & $\begin{array}{c}\text { Local } \\
\text { Guidelines }\end{array}$ & $\begin{array}{c}\text { Ease } \\
\text { of Use }\end{array}$ & None \\
\hline Surgery & 85 & 76 & & 6 & 4 & & 9 \\
\hline EVD & 51 & 69 & 5 & 16 & 19 & 1 & 16 \\
\hline JVO & 40 & 37 & 5 & 11 & 9 & 5 & 44 \\
\hline Mannitol & 81 & 66 & 5 & 17 & 10 & 5 & 3 \\
\hline Steroids & 79 &. &. & 6 & 3 & 2 & 42 \\
\hline Hypertonic saline & 72 & 40 & 2 & 12 & 5 & 3 & 32 \\
\hline Hyper-ventilation & 90 & 57 & 1 & 15 & 1 & 7 & 10 \\
\hline Phenytoin & 84 & 40 & 1 & 16 & 7 & 1 & 18 \\
\hline Cooling & 86 & 35 & 2 & 12 &. & 3 & 26 \\
\hline Nimodipine & 56 & 17 &. & 4 & 4 & 2 & 61 \\
\hline CPP-directed therapy & 107 & 84 & 7 & 8 & 3 &. & 2 \\
\hline Early enteral feeding & 99 & 78 & 13 & 7 & 5 &. & 3 \\
\hline $\begin{array}{l}\text { Intensive glucose } \\
\text { control }\end{array}$ & 96 & 76 & 7 & 9 & 7 &. & 7 \\
\hline Fever reduction & 83 & 79 & 7 & 15 & 6 &. & 5 \\
\hline NMB & 46 & 47 & 10 & 20 & 19 & 2 & 17 \\
\hline Propofol & 52 & 63 & 9 & 21 & 15 & 2 & 6 \\
\hline Narcotics & 42 & 51 & 11 & 24 & 18 & 4 & 7 \\
\hline
\end{tabular}

* - respondents replied by noting any and all factors that were applicable; totals will not add to survey of $141 ; \mathrm{EVD}=$ extraventricular drain; $\mathrm{JVO}=$ jugular venous oximetry; $\mathrm{CPP}=$ cerebral perfusion pressure; $\mathrm{NMB}=$ neuro-muscular blockade
The average agreement for the 17 manoeuvres considered was $28 \%$. Respondents had the highest frequency of 'unsure' responses for jugular venous oximetry (34\%), nimodipine $(48 \%)$, and narcotics $(30 \%)$.

When corticosteroids were considered, nearly half of respondents (46\%) cited 'evidence' as the unique significant factor affecting use of an intervention (Table 5). In the remaining 16 manoeuvres, the importance of 'evidence' as a unique factor ranged from $13 \%$ (extraventricular drain) to $38 \%$ (cooling). Among the manoeuvres that were most commonly reported as 'appropriate' and also 'frequently' used [surgery, Cerebral perfusion pressure (CPP)-directed therapy, early enteral feeding, intensive glucose control, and fever reduction], between $18 \%$ and $27 \%$ of clinicians cited 'evidence' as being the most

Table 7: Correlations of Appropriateness, Frequency of Use and Awareness of Literature for Selected Therapies (R, p value)

\begin{tabular}{l|c|c|c|c|c|c}
\hline & \multicolumn{2}{|c|}{$\begin{array}{c}\text { Awareness and } \\
\text { Appropriateness }\end{array}$} & \multicolumn{2}{c|}{$\begin{array}{c}\text { Awareness and } \\
\text { Frequency }\end{array}$} & \multicolumn{2}{c}{$\begin{array}{c}\text { Appropriateness and } \\
\text { Frequency }\end{array}$} \\
\hline & $\mathrm{R}$ & $\mathrm{p}$ & $\mathrm{R}$ & $\mathrm{p}$ & $\mathrm{R}$ & $\mathrm{p}$ \\
\hline Surgery & -0.1 & 0.23 & 0.07 & 0.39 & 0.32 & $<0.0001$ \\
\hline Steroids & -0.3 & 0.0003 & -0.05 & 0.57 & 0.33 & $<0.0001$ \\
\hline Hyperventilation & -0.18 & 0.04 & -0.13 & 0.13 & 0.64 & $<0.0001$ \\
\hline Hypertonic Saline & 0.16 & 0.06 & 0.15 & 0.08 & 0.39 & $<0.0001$ \\
\hline Mannitol & 0.10 & 0.22 & 0.15 & 0.07 & 0.53 & $<0.0001$ \\
\hline Cooling & 0.007 & 0.93 & 0.20 & 0.02 & 0.36 & $<0.0001$ \\
\hline
\end{tabular}


Table 8: Comparison of neurosurgeons' and critical care physicians' awareness of the published literature of head injury items

\begin{tabular}{l|c|c|c}
\hline & $\begin{array}{c}\text { Neurosurgeon } \\
\text { s } \\
\mathrm{n}(\%)\end{array}$ & $\begin{array}{c}\text { Critical Care Physicians } \\
\mathrm{n}(\%)\end{array}$ & $\mathrm{p} \mathrm{Value}$ \\
\hline Surgery & $23(39)$ & $36(38)$ & 0.93 \\
\hline EVD & $14(24)$ & $22(23)$ & 0.96 \\
\hline JVO & $11(19)$ & $22(23)$ & 0.49 \\
\hline Mannitol & $5(8)$ & $5(5)$ & 0.44 \\
\hline Steroids & $27(46)$ & $43(46)$ & 0.99 \\
\hline Hypertonic Saline & $13(22)$ & $42(45)$ & 0.005 \\
\hline Hyperventilation & $22(37)$ & $32(34)$ & 0.68 \\
\hline Phenytoin & $16(27)$ & $28(30)$ & 0.72 \\
\hline Cooling & $5(8)$ & $10(11)$ & 0.66 \\
\hline Nimodipine & $8(14)$ & $16(17)$ & 0.57 \\
\hline CPP-directed therapy & $21(36)$ & $31(33)$ & 0.74 \\
\hline Early enteral feeding & $6(10)$ & $14(15)$ & 0.40 \\
\hline Intensive glucose control & $12(20)$ & $55(59)$ & 0.0001 \\
\hline Fever reduction & $18(31)$ & $33(35)$ & 0.56 \\
\hline NMB & $20(34)$ & $22(23)$ & 0.16 \\
\hline Propofol sedation & $6(10)$ & $5(5)$ & 0.26 \\
\hline Narcotic sedation & $6(10)$ & $5(5)$ & \\
\hline
\end{tabular}

$\mathrm{EVD}=$ extraventricular drain; $\mathrm{JVO}=$ jugular venous oximetry;

$\mathrm{CPP}=$ cerebral perfusion pressure; $\mathrm{NMB}=$ neuro-muscular blockade

significant factor affecting use. This analysis included only respondents that indicated 'evidence' as being the unique factor driving use of a manoeuvre, and not those that indicated more than one factor as affecting the decision to use a treatment or therapy.

Table 6 describes the factors affecting clinician decision making. Clinicians were asked to note any and all factors that affected decision making; consequently, totals did not add to 141. The most common factor cited as affecting decision making was evidence from the literature, for 13 of the 17 manoeuvres, followed by availability of the intervention in the remaining 4 manoeuvres. Neither formal nor informal policy nor guidelines were reported to have a significant impact on the use of most manoeuvres.

In Table 7, the correlations between reported appropriateness, frequency of use, and agreement with literature review were considered for selected manoeuvres (surgery, steroids, hyperventilation, hypertonic saline, mannitol, and cooling). The correlations between appropriateness and frequency of use were very strong (all $\mathrm{p}$ values < 0.0001). However, the only correlation seen when agreement, appropriateness, and frequency were considered was a strong negative correlation between appropriateness and agreement with the literature review for steroids $(\mathrm{p}=0.0003)$.

In Table 8, the agreement with the literature review was compared between neurosurgeons and critical care physicians. The average agreement with the literature differed little between neurosurgeons (23\%) and critical care physicians (26\%). Significantly more critical care physicians agreed with the literature review about intensive glucose control (59\% vs $20 \%$, p $<0.0001)$, as was also seen with hypertonic saline ( $45 \%$ vs $22 \%$, $\mathrm{p}=0.005)$.

\section{DISCUSSION}

In this cross-sectional survey of Canadian intensive care physicians and neurosurgeons that treat patients with severe CHI, 57\% of eligible respondents replied (141 of 247). These physicians represented 29 of 31 sites identified as receiving and treating patients with severe CHI. Consequently, this survey provides a broad and comprehensive examination of the management of patients with severe CHI by Canadian ICU physicians and neurosurgeons, the awareness of these physicians of the published evidence, and the factors affecting management of these patients.

The survey was designed to determine areas of agreement and disagreement regarding the management of patients with relatively common types of severe closed head injury, employing therapeutic manoeuvres that are usually available in clinical practice, as determined by the expert committee. The survey was also designed to determine the factors that affect utilization of these manoeuvres, the awareness of the published evidence among respondents, and the relationship between awareness of evidence and utilization of specific therapies.

The areas of agreement and disagreement about therapies in the scenarios of acute epidural hematoma, diffuse axonal injury, and intracranial contusion have been previously reported ${ }^{2}$ and were summarized for reference (Tables 2, 3). In the setting of acute epidural hematoma, clinicians agreed strongly that surgery and mannitol were appropriate, and that steroids were not appropriate. The remaining interventions were of uncertain appropriateness. In the settings of diffuse axonal injury and intracranial contusion, respondents agreed about the appropriateness of most supportive measures, and reported that hyperventilation, use of neuromuscular blockade, and surgery were of uncertain appropriateness. No therapies were felt to be clearly inappropriate.

Considering the factors affecting the decision to employ a therapy, the single most common factor considered in combination and the most common solitary factor reported was 'published evidence'. Although 'evidence' was important, and published guidelines for the management of severe head injury exist and are available online in the public domain, 'guidelines' were seldom cited in treatment decisions. This was the case whether guidelines were considered as formal guidelines, informal guidelines, or simply usual practice. This discrepancy may be inefficient on the part of clinicians, as the peer-reviewed guideline development process is intended to simplify interpretation of the literature for clinicians and approaches to care, and hopefully to minimize unnecessary variation in practice. ${ }^{3-7}$ Consequently, determination of the cause of this discrepancy between the availability of head injury guidelines and their infrequent use by clinicians may be beneficial. Availability of the interventions was also reported to be important, but substantially less than 'evidence', suggesting broad availability of the interventions.

For most manoeuvres considered, the majority of clinicians either agreed with the formal literature review of the evidence, or was very close to agreement, although inexact. For surgery especially, clinicians were aware of the level of published evidence despite its weakness (case series, past experience, physiologic rationale, and expert opinion), ${ }^{5}$ confirming that the success of surgery to relieve compressive epidural hematoma 
with impending herniation is so obvious that non-performance of surgery in such a condition would be unethical. Interestingly, steroids for head injury, which have been evaluated in a randomized trial and found to be deleterious, were thought to be inappropriate by most respondents and were seldom used (Table 2). ${ }^{8}$ Fifty percent of the respondents indicated that at least one randomized trial had been published about steroids for the treatment of head injury, which represented the greatest agreement among respondents except for surgery (59\%). This observation provides strong inference that awareness is high among treating clinicians of this conclusive placebo-controlled trial regarding the effect of steroids in head injury; the awareness may reflect both the impact factor of the publishing journal and the very clear end-point of mortality evaluated in the study. The clarity of the evidence in that trial contrasts with the more indirect nature of the evidence regarding the other interventions considered, ${ }^{5}$ and about which clinicians showed less agreement and awareness.

There was a close correlation between reported appropriateness of the interventions and frequency of use, although neither appropriateness nor frequency correlated well with awareness of the evidence. The exception to this pattern was steroids, for which a strong negative correlation was seen between awareness of the evidence and both appropriateness and frequency of use. Again, this observation is encouraging and strongly suggests that the evidence that mitigates against the use of steroids in head injury is commonly known.

Cerebral perfusion pressure (CPP) guided therapy was considered as a single manoeuvre, but represents a complex intervention. For optimal performance, this manoeuvre requires invasive measurement of arterial pressure and intracranial pressure (ICP), of which the latter requires placement of an extraventricular drain (EVD). The CPP-directed therapy was reported to be appropriate and frequently used, and was ironically reported as more appropriate and frequently used than the EVD, which is essential for accurate use of CPP-directed therapy. While a large number of respondents correctly identified that the highest level of supporting evidence was investigational (randomized trial), ${ }^{9-10}$ a larger proportion indicated that a lower level of support existed than was seen in the literature review. While CPP-guided therapy may be important, the finding from this survey suggests that clinicians rely on evidence that is believed to be weaker than it really is. Moreover, the survey results raise suspicion that clinicians may be administering CPP-guided therapy without precise knowledge of intracranial pressure (ICP), as more clinicians reported the use of CPP-guided therapy than use of the EVD (which is required to measure ICP). Finally, the use of CPP-directed therapy is complex and it incorporates multiple variables such as target CPP (controlling MAP and ICP), intracranial drainage, EVD position and levelling, EVD type, intravascular fluid support type and volume, and amount and type of vasoactive drugs, among others. Further investigation to determine the importance and application of each of these components is appropriate.

The osmotic diuretics (mannitol and hypertonic saline) are employed to reduce the intracellular water content of normal brain tissue when ICP is elevated. Both were felt to be appropriate and frequently used by respondents, although mannitol was felt to be more appropriate and more frequently used than hypertonic saline. Whereas only $8 \%$ of respondents were aware that high-level evidence (meta-analysis) existed evaluating mannitol, a larger proportion (26\%) was aware of randomized trials for hypertonic saline. ${ }^{11-13}$ Although the lifesaving nature of surgery for compressive epidural hematoma and other lesions causing impending herniation is clear, and precludes randomized evaluation, the formal determination of the comparative effects of the osmotic diuretics is appropriate and could elucidate specific advantages of one or the other.

Supportive measures that were termed appropriate and also frequently employed in the severely head-injured included early enteral nutrition and intensive glucose control. ${ }^{14-15}$ Both of these manoeuvres have been evaluated rigourously (meta-analysis and randomized trials respectively), and respondents showed a high degree of awareness about the level of evidence. However, neither of these manoeuvres has been conclusively proven to affect outcome in their current iterations, and consequently substantial need exists for the evaluation of supportive measures in severe CHI.

Other measures that have been specifically evaluated for severe head injury, about which evidence the survey respondents were not aware (meta-analyses), include induced hypothermia and hyperventilation. ${ }^{16-20}$ Both have been controversial, and both may have specific therapeutic roles or indications that might not emerge when the severely head injured patients are considered as a homogeneous group. To this end, early induction of hypothermia is the subject of an ongoing randomized investigation. ${ }^{21}$

While the majority of respondents identified that randomized evidence exists for the use of phenytoin, there was considerable disagreement regarding several other therapies considered including sedatives, narcotics, neuromuscular blockade, nimodipine, JVO, and fever reduction..$^{22-28}$ Our review of the literature indicated that there is a lack of clear evidence for the use of these manoeuvres and further investigation to clarify the appropriateness of their implementation is warranted.

Comparison of intensive care physicians' and neurosurgeons' awareness of the literature identified only minor differences. This strongly suggests that these two groups share a similar knowledge base and practice attitude in a collaborative care model.

Strengths of this study include its design and comprehensive sampling frame. Its design included most of the commonly employed strategies for the severely head-injured, as defined by the literature review and confirmed by the expert panel. Further confirmation was found in the absence of major suggestions for additions or deletions on the part of the respondents. The high response rate to the survey and comprehensive nature of the sampling frame, taken from a census of Canadian intensive care physicians and neurosurgeons, facilitate generalization of these findings to the larger group.

Limitations of this study also relate to its design. The major limitation is probably the fact that although we were able to describe the general awareness of the literature among respondents, we were not able to investigate the interpretation of the literature (whether or not clinicians agreed with it and adopted it in practice). In some manoeuvres e.g. the 'non-use' of steroids, the awareness of the literature was so high and the consensus of the group was so clear that little doubt remained 
about interpretation of the evidence. However, this was not the case for CPP-directed therapy, the osmotic diuretics, the timing of nutrition and glucose control, nor the use of anticonvulsants, among others. As might be expected, investigation of these situations in further study would be appropriate.

In conclusion, this survey has described clinicians' attitudes and perceptions about commonly employed therapies for the management of severely head-injured patients, as well as the evidence and other factors on which these attitudes are founded. This survey suggests that the published literature is a major factor in clinician decision-making, but also that clinicians underestimate rather than overestimate the quality of the published literature; the reasons for this apparent gap in research translation should be investigated. Finally, although clinicians may be aware of the published literature regarding the management of severe head injury, their understanding of the strength and direction of recommendations remains unknown and merits further investigation.

\section{REFERENCES}

1. Zygun DA, Laupland KB, Hader WJ, Kortbeek JB, Findlay C, Doig $\mathrm{CJ}$, et al. Severe traumatic brain injury in a large Canadian health region. Can J Neurol Sci. 2005; 32(1): 87-92.

2. Jacka MJ, Zygun DA. Survey of management of severe head injury in Canada. Can J Neurol Sci. 2007; 34(3): 307-12.

3. Sekula RF, Jr., Wilberger JE. The management of traumatic brain injury: the development of guidelines and their influence. Clin Neurosurg. 2005; 52:306-10.

4. Guidelines for the management of severe traumatic brain injury. $\mathrm{J}$ Neurotrauma. 2000; 17(6/7): 450-553.

5. www.braintrauma.org, April 13, 2008.

6. Bulger EM, Nathens AB, Rivara FP, Moore M, MacKenzie EJ, Jurkovich GJ. Management of severe head injury: institutional variations in care and effect on outcome. Crit Care Med. 2002; 30(8): 1870-6.

7. Kerr J, Smith R, Gray S, Beard D, Robertson CE. An audit of clinical practice in the management of head injured patients following the introduction of the Scottish Intercollegiate Guidelines Network (SIGN) recommendations. Emerg Med J. 2005; 22(12): 850-4.

8. Roberts I, Yates D, Sandercock P, Farrell B, Wasserberg J, Lomas $\mathrm{G}$, et al. Effect of intravenous corticosteroids on death within 14 days in 10008 adults with clinically significant head injury. Lancet. 2004; 364(9442): 1321-8.

9. Prabhakaran P, Reddy AT, Oakes WJ, King WD, Winkler MK, Givens TG. A pilot trial comparing cerebral perfusion pressuretargeted therapy to intracranial pressure-targeted therapy in children with severe traumatic brain injury. J Neurosurg. 2004; 100(5 Suppl Pediatrics): 454-9.

10. Rossi S, Buzzi F, Paparella A, Mainini P, Stocchetti N. Complications and safety associated with ICP monitoring: a study of 542 patients. Acta Neurochirurgica. 1998; Supplement 71: 91-3.

11. Schierhout G, Roberts I. Mannitol for acute traumatic brain injury. Cochrane database of systematic reviews. 2003; (2): CD001049; PMID : 12804397

12. Cooper DJ, Myles PS, McDermott FT, Murray LJ, Laidlaw J, Cooper G, et al. Prehospital hypertonic saline resuscitation of patients with hypotension and severe traumatic brain injury: a randomized controlled trial. JAMA. 2004; 291(11): 1350-7.

13. Battison C, Andrews PJ, Graham C, Petty T. Randomized, controlled trial on the effect of a $20 \%$ mannitol solution and a $7.5 \%$ saline $/ 6 \%$ dextran solution on increased intracranial pressure after brain injury. Crit Care Med. 2005; 33(1): 196-202.

14. Yanagawa T, Bunn F, Roberts I, Wentz R, Pierro A. Nutritional support for head-injured patients. Cochrane Database of Systematic Reviews. 2002; (3):CD001530.
15. van den Berghe $G$, Wouters $P$, Weekers F, Verwaest $C$, Bruyninckx $\mathrm{F}$, Schetz M, et al. Intensive insulin therapy in the critically ill patients. N Engl J Med. 2001; 345(19): 1359-67.

16. Alderson P, Gadkary C, Signorini DF. Therapeutic hypothermia for head injury. Cochrane Database of Systematic Reviews. 2004; (4): CD001048.

17. Schierhout G, Roberts I. Hyperventilation therapy for acute traumatic brain injury. Cochrane Database of Systematic Reviews. 2000; (2): CD000566.

18. Muizelaar JP, Marmarou A, Ward JD, Kontos HA, Choi SC, Becker $\mathrm{DP}$, et al. Adverse effects of prolonged hyperventilation in patients with severe head injury: a randomized clinical trial. J Neurosurg. 1991;75(5): 731-9.

19. Marion DW, Penrod LE, Kelsey SF, Obrist WD, Kochanek PM, Palmer AM, et al. Treatment of traumatic brain injury with moderate hypothermia. N Engl J Med. 1997; 336(8): 540-6.

20. Clifton GL, Miller ER, Choi SC, Levin HS, McCauley S, Smith KR Jr., et al. Lack of effect of induction of hypothermia after acute brain injury. N Engl J Med. 2001; 344(8): 556-63.

21. www.clinicaltrials.gov; search $=\mathrm{NABISH}$, April 13, 2008.

22. Temkin NR, Dikmen SS, Wilensky AJ, Keihm J, Chabal S, Winn HR. A randomized, double-blind study of phenytoin for the prevention of post-traumatic seizures. N Engl J Med. 1990; 323(8): 497-502.

23. Karabinis A, Mandragos K, Stergiopoulos S, Komnos A, Soukup J, Speelberg B, et al. Safety and efficacy of analgesia-based sedation with remifentanil versus standard hypnotic-based regimens in intensive care unit patients with brain injuries: a randomised, controlled trial. Crit Care. 2004; 8(4): R268-80.

24. Pillai SV, Kolluri VR, Mohanty A, Chandramouli BA. Evaluation of nimodipine in the treatment of severe diffuse head injury: a double-blind placebo-controlled trial. Neurology India. 2003; 51(3): 361-3.

25. Mayer SA, Kowalski RG, Presciutti M, Ostapkovich ND, McGann E, Fitzsimmons BF, et al. Clinical trial of a novel surface cooling system for fever control in neurocritical care patients. Crit Care Med. 2004; 32(12): 2508-15.

26. Juul N, Morris GF, Marshall SB, Marshall LF. Neuromuscular blocking agents in neurointensive care. Acta Neurochirurgica. 2000; 76: 467-70.

27. Young KD, Okada PJ, Sokolove PE, Palchak MJ, Panacek EA, Baren JM, et al. A randomized, double-blinded, placebocontrolled trial of phenytoin for the prevention of early posttraumatic seizures in children with moderate to severe blunt head injury. Ann Emerg Med. 2004; 43(4): 435-46.

28. Gupta AK, Hutchinson PJ, Al-Rawi P, Gupta S, Swart M, Kirkpatrick PJ, et al. Measuring brain tissue oxygenation compared with jugular venous oxygen saturation for monitoring cerebral oxygenation after traumatic brain injury. Anesth Analg. 1999; 88(3): 549-53.

See Appendix on the following pages. 


\title{
Canadian Head Injury Survey
}

If you have any questions about this survey, please contact either:

\author{
Michael Jacka MD or David Zygun MD \\ Ph $7804078861 \quad$ Ph 4039441570 \\ mjacka@ualberta.ca $\quad \underline{\text { dzygun } @ \text { CalgaryHealthRegion.ca }}$
}

\section{Would you like a summary of the results of this survey? Yes /}

Dear Colleague,

The objective of this survey is to describe the current practice of clinicians regarding the treatment of patients with severe head injury. Severe head injury is defined as that which requires intensive care, as defined by usual practice at your site.

In the average year, approximately how many patients with severe head injury do you treat in your hospital?

If the previous number was 'zero', please return this survey using the enclosed stamped, self-addressed envelope. Otherwise, kindly carry on and complete the survey.

When completing the rest of this survey, 'appropriate' means that the benefit of an intervention exceeds the risk. In all scenarios, the toxicology screen is negative for drugs and alcohol.

Section I

In this section, please consider your responses to the following scenario:

An 18-year-old male was injured during an assault. Emergency response personnel found him in a parking lot, approximately 20 minutes after the original injury. On your assessment in hospital, his eyes are closed and he withdraws from painful stimuli. He has been intubated. His CT scan is seen below. Based on this clinical description, please respond to the questions on the subsequent pages.

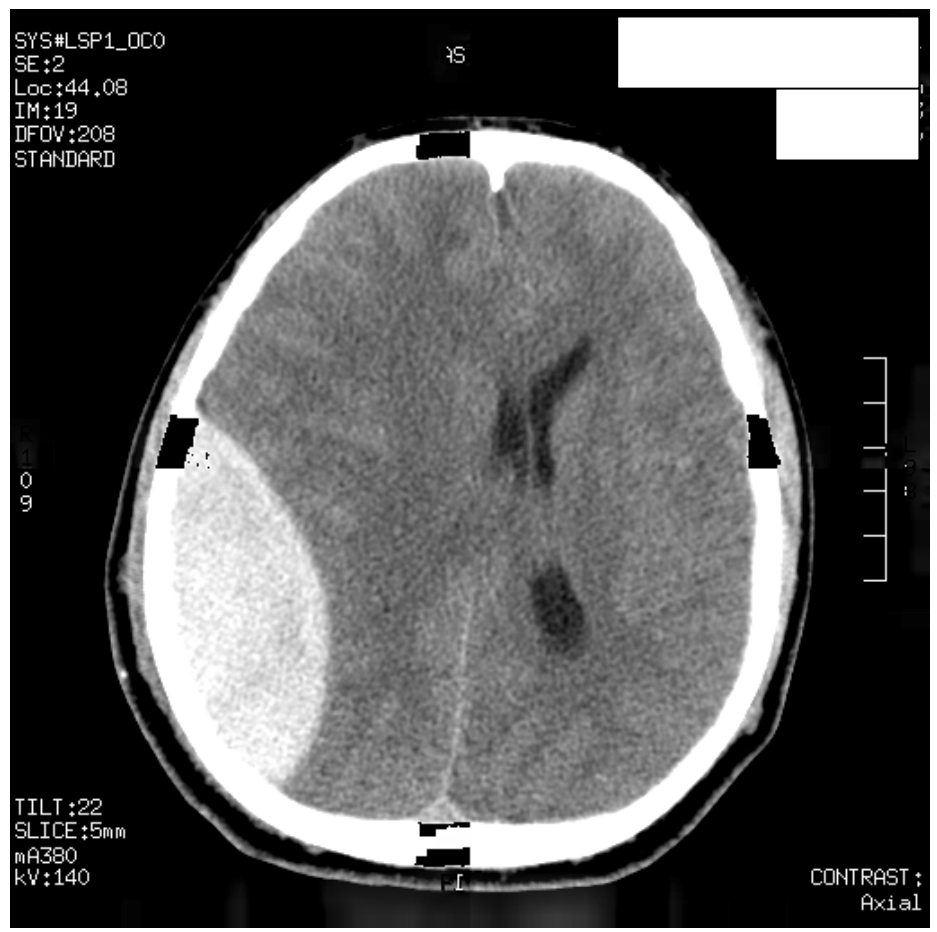




\section{Section I: Interventions for Head Injury Treatment}

1- How appropriate are each of these interventions for the treatment of head injury in this scenario? Please check only one response option, below, for each intervention.

\begin{tabular}{|c|c|c|c|c|c|c|c|c|c|c|}
\hline Appropriateness: & Surgery & $\begin{array}{c}\text { Intra-ventricular } \\
\text { Drain }\end{array}$ & $\begin{array}{c}\text { Jugular Bulb } \\
\text { Catheter }\end{array}$ & Mannitol & $\begin{array}{l}\text { Cortico- } \\
\text { steroids }\end{array}$ & $\begin{array}{l}\text { Hypertonic } \\
\text { saline }\end{array}$ & Hyperventilation & Phenytoin & Cooling & Nimodipine \\
\hline Definitely harmful & & & & & & & & & & \\
\hline Probably harmful & & & & & & & & & & \\
\hline Possibly harmful & & & & & & & & & & \\
\hline No net effect & & & & & & & & & & \\
\hline Possibly beneficial & & & & & & & & & & \\
\hline Probably beneficial & & & & & & & & & & \\
\hline Definitely beneficial & & & & & & & & & & \\
\hline Do not know & & & & & & & & & & \\
\hline
\end{tabular}

2- What level of evidence do you believe exists to support these decisions? Please check all those that apply.

\begin{tabular}{|c|c|c|c|c|c|c|c|c|c|c|}
\hline Level of Evidence: & Surgery & $\begin{array}{c}\text { Intra-ventricular } \\
\text { Drain }\end{array}$ & $\begin{array}{l}\text { Jugular Bulb } \\
\text { Catheter }\end{array}$ & Mannitol & $\begin{array}{l}\text { Cortico- } \\
\text { steroids }\end{array}$ & $\begin{array}{l}\text { Hypertonic } \\
\text { saline }\end{array}$ & Hyperventilation & Phenytoin & Cooling & Nimodipine \\
\hline \multicolumn{11}{|c|}{ Meta-analysis of RCTs } \\
\hline \multicolumn{11}{|l|}{ One or more RCTs } \\
\hline \multicolumn{11}{|c|}{$\begin{array}{l}\text { Observational studies } \\
\text { (cohort or case control) }\end{array}$} \\
\hline \multicolumn{11}{|l|}{ Case series } \\
\hline \multicolumn{11}{|l|}{ Physiologic rationale } \\
\hline \multicolumn{11}{|l|}{ Personal experience } \\
\hline \multicolumn{11}{|l|}{ Expert opinion } \\
\hline $\begin{array}{l}\text { Unsure of level of } \\
\text { available evidence }\end{array}$ & & & & & & & & & & \\
\hline
\end{tabular}

3. Do you currently use these interventions to treat head injury in this setting? Please check only one response option for each intervention.

\begin{tabular}{|c|c|c|c|c|c|c|c|c|c|c|}
\hline Frequency of use of item: & Surgery & $\begin{array}{l}\text { Intra-ventricular } \\
\text { Drain }\end{array}$ & $\begin{array}{l}\text { Jugular Bulb } \\
\text { Catheter }\end{array}$ & Mannitol & $\begin{array}{l}\text { Cortico- } \\
\text { steroids }\end{array}$ & $\begin{array}{l}\text { Hypertonic } \\
\text { saline }\end{array}$ & Hyperventilation & Phenytoin & Cooling & Nimodipine \\
\hline Always, in all patients & & & & & & & & & & \\
\hline $\begin{array}{l}\text { Always, in selected } \\
\text { patients } \\
\text { (please specify) }\end{array}$ & & & & & & & & & & \\
\hline $\begin{array}{l}\text { Sometimes, in selected } \\
\text { patients } \\
\text { (please specify) }\end{array}$ & & & & & & & & & & \\
\hline Rarely & & & & & & & & & & \\
\hline Never & & & & & & & & & & \\
\hline
\end{tabular}

4. Which factors influence the frequency with which you utilize these interventions in this scenario? Please indicate all those that apply.

\begin{tabular}{|c|c|c|c|c|c|c|c|c|c|c|}
\hline $\begin{array}{l}\text { Factors influencing } \\
\text { frequency of use of items: }\end{array}$ & Surgery & $\begin{array}{c}\text { Intra-ventricular } \\
\text { Drain }\end{array}$ & $\begin{array}{c}\text { Jugular Bulb } \\
\text { Catheter }\end{array}$ & Mannitol & $\begin{array}{l}\text { Cortico- } \\
\text { steroids }\end{array}$ & $\begin{array}{l}\text { Hypertonic } \\
\text { saline }\end{array}$ & Hyperventilation & Phenytoin & Cooling & Nimodipine \\
\hline $\begin{array}{l}\text { Awareness of published } \\
\text { evidence }\end{array}$ & & & & & & & & & & \\
\hline $\begin{array}{l}\text { Availability of } \\
\text { intervention }\end{array}$ & & & & & & & & & & \\
\hline $\begin{array}{l}\text { Formal (documented) ICU } \\
\text { policy }\end{array}$ & & & & & & & & & & \\
\hline $\begin{array}{l}\text { Informal ICU policy } \\
\text { (reflects usual local } \\
\text { practice) }\end{array}$ & & & & & & & & & & \\
\hline Local practice guidelines & & & & & & & & & & \\
\hline Ease of use & & & & & & & & & & \\
\hline None & & & & & & & & & & \\
\hline
\end{tabular}




\section{Section II}

In this section, please consider your responses to the following scenario:

An 18 -year-old male was injured in a motor vehicle accident at highway speeds. Emergency response personnel found him at the scene, approximately 30 minutes after the accident. He was the seat-belted driver. On your assessment in hospital, his eyes are closed and he flexes to painful stimuli. He has been intubated. Two cuts of his CT scan are seen below. Based on this clinical description, please respond to the questions on the subsequent pages.

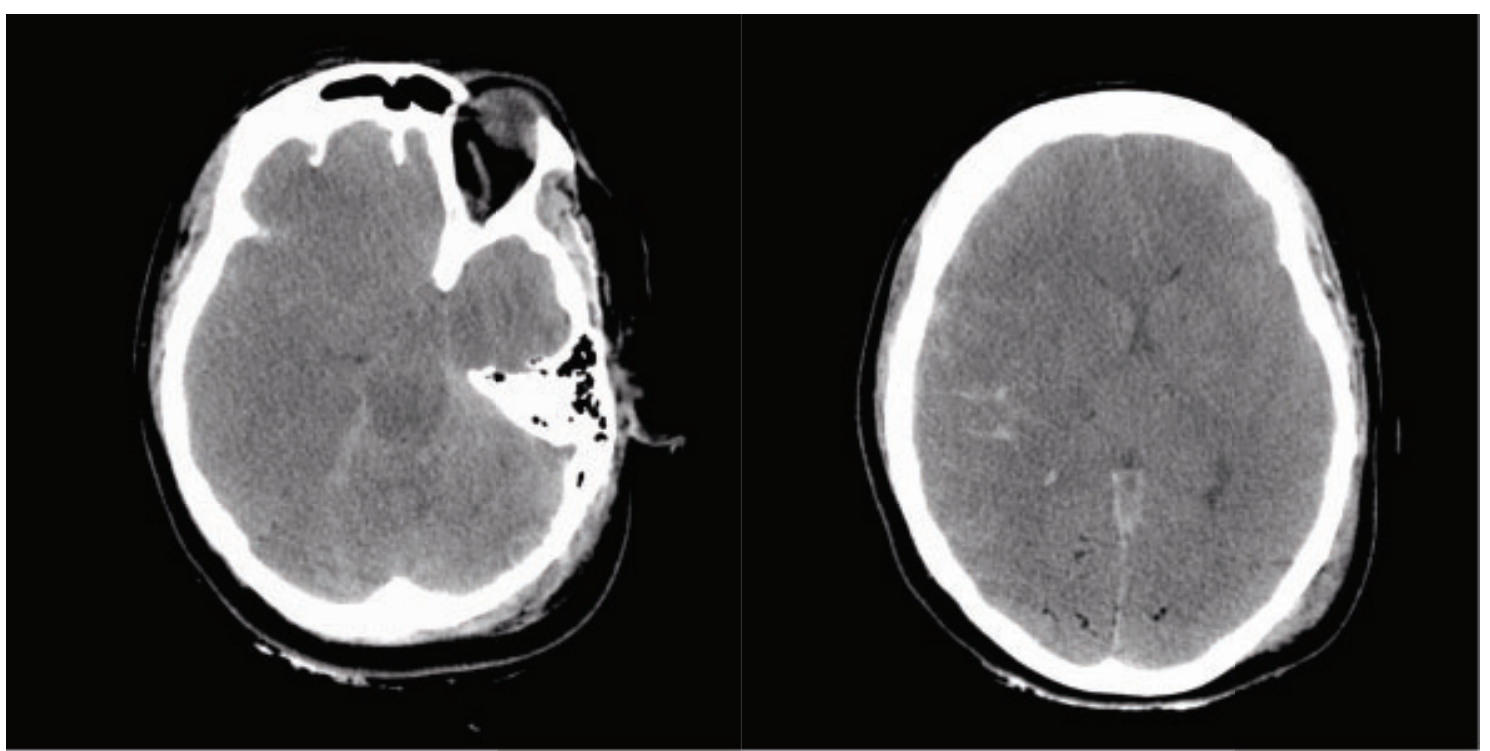

Section II: Interventions for Head Injury Treatment

1- How appropriate are each of these interventions currently, or likely to be, for the treatment of head injury in this patient? Please check only one response option, for each intervention.

\begin{tabular}{|c|c|c|c|c|c|c|c|c|c|c|c|c|c|}
\hline Appropriateness: & Surgery & $\begin{array}{c}\text { Hyper- } \\
\text { ventilation }\end{array}$ & $\begin{array}{c}\text { CPP- } \\
\text { directed } \\
\text { therapy }\end{array}$ & Mannitol & $\begin{array}{l}\text { Hypertonic } \\
\text { Saline }\end{array}$ & $\begin{array}{c}\text { Early } \\
\text { Enteral } \\
\text { Feeding }\end{array}$ & $\begin{array}{c}\text { Intensive } \\
\text { Glucose } \\
\text { Control } \\
\end{array}$ & $\begin{array}{c}\text { Fever } \\
\text { Reduction }\end{array}$ & $\begin{array}{l}\text { Jugular } \\
\text { Bulb } \\
\text { Catheter }\end{array}$ & $\begin{array}{c}\text { Muscle } \\
\text { Relaxants }\end{array}$ & Propofol & Narcotic & $\begin{array}{c}\text { Intra } \\
\text { Ventricular } \\
\text { Drain } \\
\end{array}$ \\
\hline Definitely harmful & & & & & & & & & & & & & \\
\hline Probably harmful & & & & & & & & & & & & & \\
\hline Possibly harmful & & & & & & & & & & & & & \\
\hline No net effect & & & & & & & & & & & & & \\
\hline Possibly beneficial & & & & & & & & & & & & & \\
\hline Probably beneficial & & & & & & & & & & & & & \\
\hline $\begin{array}{l}\text { Definitely } \\
\text { beneficial }\end{array}$ & & & & & & & & & & & & & \\
\hline Do not know & & & & & & & & & & & & & \\
\hline
\end{tabular}

2- What level of evidence do you believe exists to support these decisions? Please check all those that apply

\begin{tabular}{|c|c|c|c|c|c|c|c|c|c|c|c|c|c|}
\hline Level of Evidence: & Surgery & $\begin{array}{c}\text { Hyper- } \\
\text { ventilation }\end{array}$ & $\begin{array}{c}\text { CPP- } \\
\text { directed } \\
\text { therapy }\end{array}$ & Mannitol & $\begin{array}{l}\text { Hypertonic } \\
\text { Saline }\end{array}$ & $\begin{array}{c}\text { Early } \\
\text { Enteral } \\
\text { Feeding }\end{array}$ & $\begin{array}{c}\text { Intensive } \\
\text { Glucose } \\
\text { Control }\end{array}$ & $\begin{array}{c}\text { Fever } \\
\text { Reduction }\end{array}$ & $\begin{array}{l}\text { Jugular } \\
\text { Bulb } \\
\text { Catheter }\end{array}$ & $\begin{array}{c}\text { Muscle } \\
\text { Relaxants }\end{array}$ & Propofol & Narcotic & $\begin{array}{c}\text { Intra } \\
\text { Ventricular } \\
\text { Drain }\end{array}$ \\
\hline $\begin{array}{l}\text { Meta-analysis of } \\
\text { RCTs }\end{array}$ & & & & & & & & & & & & & \\
\hline One or more RCTs & & & & & & & & & & & & & \\
\hline $\begin{array}{l}\text { Observational } \\
\text { studies } \\
\text { (cohort or case } \\
\text { control) }\end{array}$ & & & & & & & & & & & & & \\
\hline Case series & & & & & & & & & & & & & \\
\hline $\begin{array}{l}\text { Physiologic } \\
\text { rationale }\end{array}$ & & & & & & & & & & & & & \\
\hline Personal experience & & & & & & & & & & & & & \\
\hline Expert opinion & & & & & & & & & & & & & \\
\hline $\begin{array}{l}\text { Unsure of level of } \\
\text { available evidence }\end{array}$ & & & & & & & & & & & & & \\
\hline
\end{tabular}




\section{Section II: Interventions for Head Injury Treatment (continued)}

3. Do you currently use these interventions to treat head injury in this setting? Please check only one response option for each intervention.

\begin{tabular}{|c|c|c|c|c|c|c|c|c|c|c|c|c|c|}
\hline $\begin{array}{l}\text { Frequency of use of } \\
\text { item: }\end{array}$ & Surgery & $\begin{array}{c}\text { Hyper- } \\
\text { ventilation }\end{array}$ & $\begin{array}{c}\text { CPP- } \\
\text { directed } \\
\text { therapy }\end{array}$ & Mannitol & $\begin{array}{l}\text { Hypertonic } \\
\text { Saline }\end{array}$ & $\begin{array}{c}\text { Early } \\
\text { Enteral } \\
\text { Feeding }\end{array}$ & $\begin{array}{l}\text { Intensive } \\
\text { Glucose } \\
\text { Control }\end{array}$ & $\begin{array}{c}\text { Fever } \\
\text { Reduction }\end{array}$ & $\begin{array}{c}\text { Jugular } \\
\text { Bulb } \\
\text { Catheter }\end{array}$ & $\begin{array}{c}\text { Muscle } \\
\text { Relaxants }\end{array}$ & Propofol & Narcotic & $\begin{array}{c}\text { Intra } \\
\text { Ventricular } \\
\text { Drain } \\
\end{array}$ \\
\hline $\begin{array}{l}\text { Always, in all } \\
\text { patients }\end{array}$ & & & & & & & & & & & & & \\
\hline $\begin{array}{l}\text { Always, in selected } \\
\text { patients } \\
\text { (please specify) }\end{array}$ & & & & & & & & & & & & & \\
\hline $\begin{array}{l}\text { Sometimes, in } \\
\text { selected patients } \\
\text { (please specify) }\end{array}$ & & & & & & & & & & & & & \\
\hline Rarely & & & & & & & & & & & & & \\
\hline Never & & & & & & & & & & & & & \\
\hline
\end{tabular}

4. Which factors influence the frequency with which you utilize these interventions in this scenario? Please indicate all those that apply.

\begin{tabular}{|c|c|c|c|c|c|c|c|c|c|c|c|c|c|}
\hline $\begin{array}{l}\text { Factors influencing } \\
\text { frequency of use of } \\
\text { items: }\end{array}$ & Surgery & $\begin{array}{c}\text { Hyper- } \\
\text { ventilation }\end{array}$ & $\begin{array}{l}\text { CPP- } \\
\text { directed } \\
\text { therapy }\end{array}$ & Mannitol & $\begin{array}{l}\text { Hypertonic } \\
\text { Saline }\end{array}$ & $\begin{array}{c}\text { Early } \\
\text { Enteral } \\
\text { Feeding }\end{array}$ & $\begin{array}{l}\text { Intensive } \\
\text { Glucose } \\
\text { Control }\end{array}$ & $\begin{array}{c}\text { Fever } \\
\text { Reduction }\end{array}$ & $\begin{array}{l}\text { Jugular } \\
\text { Bulb } \\
\text { Catheter }\end{array}$ & $\begin{array}{c}\text { Muscle } \\
\text { Relaxants }\end{array}$ & Propofol & Narcotic & $\begin{array}{c}\text { Intra } \\
\text { Ventricular } \\
\text { Drain }\end{array}$ \\
\hline $\begin{array}{l}\text { Awareness of } \\
\text { published evidence }\end{array}$ & & & & & & & & & & & & & \\
\hline $\begin{array}{l}\text { Availability of } \\
\text { intervention }\end{array}$ & & & & & & & & & & & & & \\
\hline $\begin{array}{l}\text { Formal } \\
\text { (documented) ICU } \\
\text { policy }\end{array}$ & & & & & & & & & & & & & \\
\hline $\begin{array}{l}\text { Informal ICU policy } \\
\text { (reflects usual local } \\
\text { practice) }\end{array}$ & & & & & & & & & & & & & \\
\hline $\begin{array}{l}\text { Local practice } \\
\text { guidelines }\end{array}$ & & & & & & & & & & & & & \\
\hline Ease of use & & & & & & & & & & & & & \\
\hline None & & & & & & & & & & & & & \\
\hline
\end{tabular}

In this section, please consider your responses to the following scenario:

An 18-year-old male was injured during a fall. Emergency response personnel found him at the scene, approximately 10 minutes after the accident. On your assessment in hospital, his eyes are closed and he withdraws from painful stimuli. He has been intubated. His CT scan is seen below. Based on this clinical description, please respond to the questions on the subsequent pages.

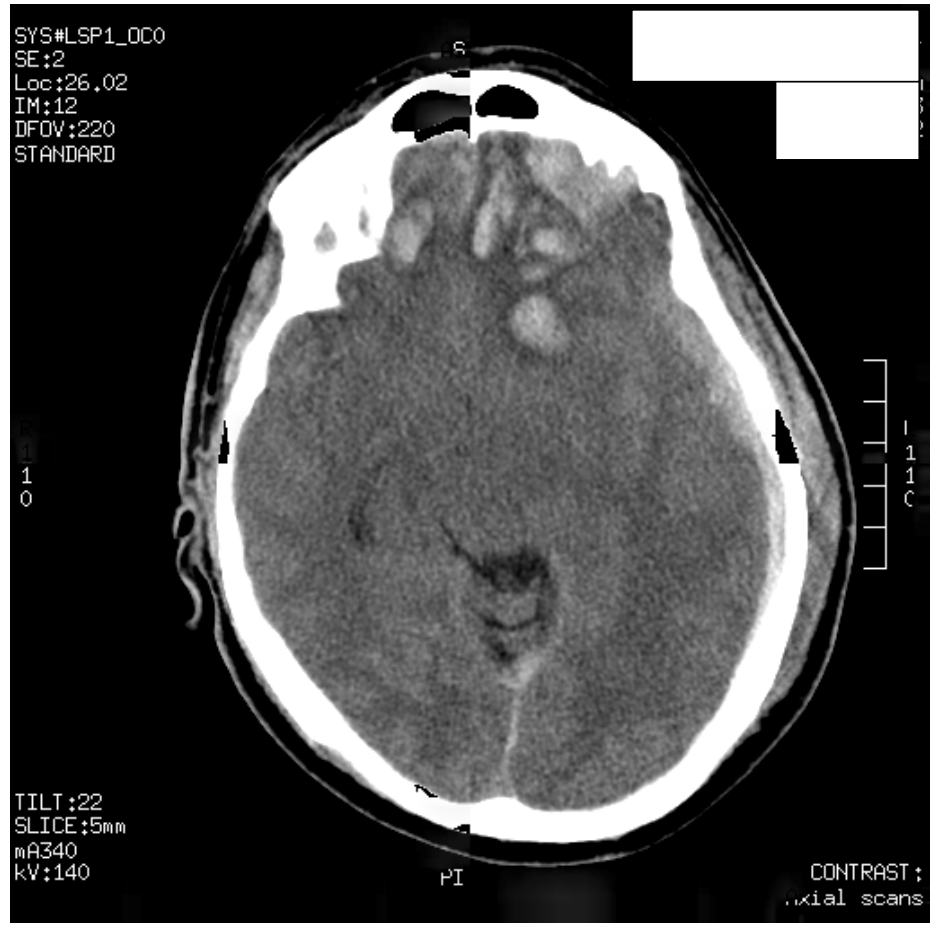


Section III: Interventions for Head Injury Treatmen

1- How appropriate are each of these interventions currently, or likely to be, for the treatment of head injury in this patient? Please check only one response option, for each

\begin{tabular}{|c|c|c|c|c|c|c|c|c|c|c|c|c|c|}
\hline Appropriateness: & Surgery & $\begin{array}{c}\text { Hyper- } \\
\text { ventilation }\end{array}$ & $\begin{array}{c}\text { CPP- } \\
\text { directed } \\
\text { therapy }\end{array}$ & Mannitol & $\begin{array}{l}\text { Hypertonic } \\
\text { Saline }\end{array}$ & $\begin{array}{c}\text { Early } \\
\text { Enteral } \\
\text { Feeding } \\
\end{array}$ & $\begin{array}{c}\text { Intensive } \\
\text { Glucose } \\
\text { Control } \\
\end{array}$ & $\begin{array}{c}\text { Fever } \\
\text { Reduction }\end{array}$ & $\begin{array}{l}\text { Jugular } \\
\text { Bulb } \\
\text { Catheter }\end{array}$ & $\begin{array}{c}\text { Muscle } \\
\text { Relaxants }\end{array}$ & Propofol & Narcotic & $\begin{array}{c}\text { Intra } \\
\text { Ventricular } \\
\text { Drain } \\
\end{array}$ \\
\hline Definitely harmful & & & & & & & & & & & & & \\
\hline Probably harmful & & & & & & & & & & & & & \\
\hline Possibly harmful & & & & & & & & & & & & & \\
\hline No net effect & & & & & & & & & & & & & \\
\hline Possibly beneficial & & & & & & & & & & & & & \\
\hline Probably beneficial & & & & & & & & & & & & & \\
\hline $\begin{array}{l}\text { Definitely } \\
\text { beneficial } \\
\end{array}$ & & & & & & & & & & & & & \\
\hline Do not know & & & & & & & & & & & & & \\
\hline
\end{tabular}

2- What level of evidence do you believe exists to support these decisions? Please check all those that apply.

\begin{tabular}{|c|c|c|c|c|c|c|c|c|c|c|c|c|c|}
\hline Level of Evidence: & Surgery & $\begin{array}{c}\text { Hyper- } \\
\text { ventilation }\end{array}$ & $\begin{array}{c}\text { CPP- } \\
\text { directed } \\
\text { therapy }\end{array}$ & Mannitol & $\begin{array}{l}\text { Hypertonic } \\
\text { Saline }\end{array}$ & $\begin{array}{c}\text { Early } \\
\text { Enteral } \\
\text { Feeding }\end{array}$ & $\begin{array}{c}\text { Intensive } \\
\text { Glucose } \\
\text { Control }\end{array}$ & $\begin{array}{c}\text { Fever } \\
\text { Reduction }\end{array}$ & $\begin{array}{c}\text { Jugular } \\
\text { Bulb } \\
\text { Catheter }\end{array}$ & $\begin{array}{c}\text { Muscle } \\
\text { Relaxants }\end{array}$ & Propofol & Narcotic & $\begin{array}{c}\text { Intra } \\
\text { Ventricular } \\
\text { Drain }\end{array}$ \\
\hline $\begin{array}{l}\text { Meta-analysis of } \\
\text { RCTs }\end{array}$ & & & & & & & & & & & & & \\
\hline One or more RCTs & & & & & & & & & & & & & \\
\hline $\begin{array}{l}\text { Observational } \\
\text { studies } \\
\text { (cohort or case } \\
\text { control) }\end{array}$ & & & & & & & & & & & & & \\
\hline Case series & & & & & & & & & & & & & \\
\hline $\begin{array}{l}\text { Physiologic } \\
\text { rationale }\end{array}$ & & & & & & & & & & & & & \\
\hline Personal experience & & & & & & & & & & & & & \\
\hline Expert opinion & & & & & & & & & & & & & \\
\hline $\begin{array}{l}\text { Unsure of level of } \\
\text { available evidence }\end{array}$ & & & & & & & & & & & & & \\
\hline
\end{tabular}

Section III: Interventions for Head Injury Treatment (continued)

3. Do you currently use these interventions to treat head injury in this setting? Please check only one response option for each intervention.

\begin{tabular}{|c|c|c|c|c|c|c|c|c|c|c|c|c|c|}
\hline $\begin{array}{l}\text { Frequency of use of } \\
\text { item: }\end{array}$ & Surgery & $\begin{array}{c}\text { Hyper- } \\
\text { ventilation }\end{array}$ & $\begin{array}{c}\text { CPP- } \\
\text { directed } \\
\text { therapy }\end{array}$ & Mannitol & $\begin{array}{l}\text { Hypertonic } \\
\text { Saline }\end{array}$ & $\begin{array}{c}\text { Early } \\
\text { Enteral } \\
\text { Feeding }\end{array}$ & $\begin{array}{l}\text { Intensive } \\
\text { Glucose } \\
\text { Control }\end{array}$ & $\begin{array}{c}\text { Fever } \\
\text { Reduction }\end{array}$ & $\begin{array}{l}\text { Jugular } \\
\text { Bulb } \\
\text { Catheter }\end{array}$ & $\begin{array}{c}\text { Muscle } \\
\text { Relaxants }\end{array}$ & Propofol & Narcotic & $\begin{array}{c}\text { Intra } \\
\text { Ventricular } \\
\text { Drain }\end{array}$ \\
\hline $\begin{array}{l}\text { Always, in all } \\
\text { patients }\end{array}$ & & & & & & & & & & & & & \\
\hline $\begin{array}{l}\text { Always, in selected } \\
\text { patients } \\
\text { (please specify) }\end{array}$ & & & & & & & & & & & & & \\
\hline $\begin{array}{l}\text { Sometimes, in } \\
\text { selected patients } \\
\text { (please specify) }\end{array}$ & & & & & & & & & & & & & \\
\hline Rarely & & & & & & & & & & & & & \\
\hline Never & & & & & & & & & & & & & \\
\hline
\end{tabular}

4. Which factors influence the frequency with which you utilize these interventions in this scenario? Please indicate all those that apply.

\begin{tabular}{|c|c|c|c|c|c|c|c|c|c|c|c|c|c|}
\hline $\begin{array}{l}\text { Factors influencing } \\
\text { frequency of use of } \\
\text { items: }\end{array}$ & Surgery & $\begin{array}{c}\text { Hyper- } \\
\text { ventilation }\end{array}$ & $\begin{array}{c}\text { CPP- } \\
\text { directed } \\
\text { therapy }\end{array}$ & Mannitol & $\begin{array}{l}\text { Hypertonic } \\
\text { Saline }\end{array}$ & $\begin{array}{c}\text { Early } \\
\text { Enteral } \\
\text { Feeding }\end{array}$ & $\begin{array}{l}\text { Intensive } \\
\text { Glucose } \\
\text { Control }\end{array}$ & $\begin{array}{c}\text { Fever } \\
\text { Reduction }\end{array}$ & $\begin{array}{l}\text { Jugular } \\
\text { Bulb } \\
\text { Catheter }\end{array}$ & $\begin{array}{c}\text { Muscle } \\
\text { Relaxants }\end{array}$ & Propofol & Narcotic & $\begin{array}{c}\text { Intra } \\
\text { Ventricular } \\
\text { Drain }\end{array}$ \\
\hline $\begin{array}{l}\text { Awareness of } \\
\text { published evidence }\end{array}$ & & & & & & & & & & & & & \\
\hline $\begin{array}{l}\text { Availability of } \\
\text { intervention }\end{array}$ & & & & & & & & & & & & & \\
\hline $\begin{array}{l}\text { Formal } \\
\text { (documented) ICU } \\
\text { policy }\end{array}$ & & & & & & & & & & & & & \\
\hline $\begin{array}{l}\text { Informal ICU policy } \\
\text { (reflects usual local } \\
\text { practice) }\end{array}$ & & & & & & & & & & & & & \\
\hline $\begin{array}{l}\text { Local practice } \\
\text { guidelines }\end{array}$ & & & & & & & & & & & & & \\
\hline Ease of use & & & & & & & & & & & & & \\
\hline None & & & & & & & & & & & & & \\
\hline
\end{tabular}


In this section, please tell us a little about yourself:

1. What is your age?

a. $<40$

b. $40-49$

c. $50-59$

d. $>59$

2. What is your gender?

a. male
b. female

3. For how many years have you been in practice (a number)?

4. What certification do you hold? (Please circle all that are applicable)

a. College of Family Physicians of Canada

b. General License

c. Royal College of Physicians and Surgeons of Canada

d. Other (please specify)

5. What, if any, specialist certification do you hold? (Please circle all that are applicable)

a. none

c. internal medicine

d.anesthesiology

e. surgery

f. other (please specify)

6. What, if any, critical care certification do you hold? (Please circle all that are applicable)

a. none
b. one-year fellowship (Canada)

c. two-year fellowship (Canada)

d. other (please specify)

7. What type of patients are seen in the intensive care unit in which you practice? (Please circle all that are applicable)

a. medical

b. surgical

c. neurosurgical

d. trauma

e. burns

f. other (please specify)

8. What age group of patients are seen in you unit?

a. adult

b. pediatric $(<18$ years $)$

c. both

9. Do you have residents or fellows training in your practice?

a. yes

10. How many beds are usually staffed in your intensive care unit? (A number)

11. Approximately what proportion of patients are ventilated, on average, in your unit?

a. $<25 \%$

b. $26-50 \%$

c. $51-75 \%$

d. $>75 \%$

12. What model better describes the referral pattern for your unit?

a. secondary
b. tertiary

13. What is the approximate number of beds staffed in your hospital?

a. $<100$

b. $100-400$

c. $410-750$

d. $>750$

14. What is the approximate population of the city in which your hospital is located?

a. $<50000$

b. $50000-100000$

c. $100001-250000$

c. $2500000-500000$

e. $>500000$

15. What model best describes the care provided in your unit for the majority of patients with head injury?

a. completely open, each patient in the unit cared for by a different physician

b. open consultative, with the admitting physician providing most aspects of care but assigning the ventilatory care to another physician

c. open consultative, where the care of patients with head injury is transferred to another physician

d. closed, where all patients admitted to the unit are transferred to the care of another physician

16. Approximately how many patients with isolated severe head injury are seen in your unit in an average year? (A number)

17. Approximately how many patients with multiple trauma (including severe head injury) are seen in your unit in an average year? (A number)

18. In your experience, what has happened to the incidence of head injury?

a. increased
b. decreased

c. remained the same 
19. In your experience, what has happened to the survival of patients with head injury?

a. increased

b. decreased

c. remained the same

20. What, if anything, do you think has accounted for this effect on the incidence and survival of patients with head injury?

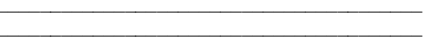

21. Finally, do you have any comments or suggestions? 